\title{
PENEGAKAN HUKUM PADA TAHAP PENYIDIKAN TINDAK PIDANA PENCURIAN KELAPA SAWIT MILIK PT SUMBAR ANDALAS KENCANA DI SATRESKRIM POLRES PESISIR SELATAN
}

\author{
Hokianto Tanjaya \\ Program Magister Ilmu Hukum,Universitas Ekasakti, Padang \\ Email: hoki_tan@yahoo.com
}

\begin{abstract}
Law enforcement at the stage of the investigation of the crime of palm oil theft belonging to PT West Sumatra Andalas Kencana at the Satreskrim Polres Pesisir Selatan is by means of penal mediation and through the criminal justice system in this case during the investigation process. The settlement efforts made against the perpetrators of the crime of palm oil theft, if they have committed the crime of theft for the first time, the perpetrators will only be given guidance, must report, and declare that they will not repeat the crime of palm oil theft. When the crime of theft is repeated, then the perpetrator is processed to the stage of examination in court. In law enforcement against perpetrators of theft the victim prefers a mediation settlement because the victim recovers the stolen palm oil and there is compensation for losses. Obstacles in Law Enforcement at the Investigation Stage of the Crime of Palm Oil Theft belonging to PT West Sumatra Andalas Kencana at the South Pesisir Selatan Police Criminal Investigation Unit, including the number of personnel from investigators assigned to the Pesisir Selatan Police is very small, not in accordance with the number of cases of oil palm theft that exist. The people of Pesisir Selatan Regency prefer to settle the case with the prevailing custom, but this method does not have a deterrent effect, this can be seen from the frequent repetition of the crime of palm oil theft on plantations belonging to PT West Sumatra Andalas Kencana. The long distance between the police station and the oil palm plantations must require an adequate operational/transportation car, as well as the obstacles experienced during the investigation stage.
\end{abstract}

Keywords: Investigation, Palm Oil, Crime of Theft, Law Enforcement

\section{ABSTRAK}

Penegakan Hukum Pada Tahap Penyidikan Terhadap Tindak Pidana Pencurian Kelapa Sawit Milik PT Sumbar Andalas Kencana di Satreskrim Polres Pesisir Selatan adalah dengan cara mediasi penal dan melalui sistem peradilan pidana dalam hal ini pada proses penyidikan. Upaya penyelesaian yang dilakukan terhadap pelaku tindak pidana pencurian kelapa sawit tersebut jika baru sekali melakukan tindak pidana pencurian maka terhadap pelaku hanya diberikan pembinaan, wajib lapor, dan pernyataan tidak akan mengulangi lagi tindak pidana pencurian kelapa sawit tersebut. Ketika tindak pidana pencurian itu berulang barulah terhadap pelaku diproses hingga ke tahap pemeriksaan di pengadilan. Pada penegakan hukum terhadap pelaku pencurian korban lebih memilih penyelesaian secara mediasi karena korban memperoleh kembali kelapa sawitnya yang dicuri dan adanya pengganti kerugian. kendala dalam Penegakan Hukum Pada Tahap Penyidikan Terhadap Tindak Pidana Pencurian Kelapa 
Sawit Milik PT Sumbar Andalas Kencana di Satreskrim Polres Pesisir Selatan diantaranya adalah jumlah personil dari penyidik yang bertugas di Polres Pesisir Selatan sangat sedikit tidak sesuai dengan banyaknya kasus pencurian kelapa sawit yang ada. Masyarakat Kabupaten Pesisir Selatan lebih memilih menyelesaikan kasus tersebut dengan adat yang berlaku namun cara ini tidak menimbulkan efek jera, hal ini terlihat seringnya dilakukan pengulangan tindak pidana pencurian kelapa sawit pada perkebunan milik PT Sumbar Andalas Kencana. Jarak antara kantor kepolisian dengan kebun sawit yang jauh harus memerlukan mobil operasional/transportasi yang memadai, juga kendala yang dirasakan dalam tahap pen yidikan.

Kata Kunci: Penyidikan, Kelapa Sawit, Tindak Pidana Pencurian, Penegakan Hukum

\section{PENDAHULUAN}

Sesuai dengan Pasal 7 KUHAP tentang kewenangan-kewenangan penyidik dalam melaksanakan kewajibannya dan Pasal 14 ayat (1) huruf g Undang-undang Nomor 2 tahun 2002 tentang Kepolisian Negara Republik Indonesia, yang menyatakan bahwa dalam melaksanakan tugas pokok sebagaimana yang dimaksud dalam Pasal 13, Kepolisian Negara Republik Indonesia yang bertugas melakukan penyelidikan dan penyidikan terhadap semua tindak pidana harus sesuai dengan hukum acara pidana dan peraturan perundangundangan lainnya. Penyidikan dilakukan untuk mengumpulkan bukti bukti sesuai dengan unsur unsur yang terdapat pada tindak pidana yang disangkakan. Polres Pesisir Selatan mempunyai tugas dan wewenang dalam penyidikan tindak pidana umum.

Salah satu perusahaan perkebunan di Sumatera Barat adalah PT Sumbar AndalasKencana merupakan Perusahaan yang bergerak di bidang perkebunan dan pengolahan Kelapa Sawit yang saat ini sudah memiliki areal perkebunan kelapa sawit seluas $80.000 \mathrm{Ha}$. Selain dari lahan yang dimiliki perusahaan, terdapat juga $60.000 \mathrm{Ha}$ lahan plasma yang juga dikelola oleh PT Sumbar Andalas Kencana. Saat ini PT Sumbar Andalas Kencana sudah memiliki 13 Pabrik Kelapa Sawit (PKS) dengan kapasitas produksi 915 ton/jam dan pasokan tandan buah segar (TBS) sebanyak 5,5 juta ton per tahun. Kondisi tersebut membuat rentan terjadi pencurian kelapa sawit. ${ }^{1}$

Proses pemeriksaan tentang benar tidaknya suatu perbuatan pidana itu terjadi, dapat diketahui melalui proses penyidikan, tetapi sebelum dilakukan penyidikan terlebih dahulu dilakukan proses penyelidikan yang dilakukan oleh penyelidik. ${ }^{2}$

Kejahatan yang telah dilaporkan/diadukan haruslah sudah ada peraturan perundangundangan yang mengaturnya, sehingga jika peraturan tidak mengatur maka seharusnya seseorang tersebut bebas dari segala tuntutan hukum ${ }^{3}$ Suatu perbuatan tidak dapat dipidana, kecuali berdasarkan kekuatan ketentuan perundang-undangan yang telah ada dengan didasarkan adagium nullum delictum noela poenna praevia sine lege poenale sebagaimana dicantumkan dalam Pasal 1 Kitab Undang undang Hukum Pidana. ${ }^{4}$

Penegakan hukum terhadap tindak pidana pencurian seperti tindak pidana pencurian yang terjadi pada wilayah perkebunan kelapa sawit milik PT Sumbar Andalas Kencana (SAK)

\footnotetext{
${ }^{1}$ Prapenelitian pada PT Incasi Raya Sumbar tahun 2020.

${ }^{2}$ Leden Marpaung, Proses Penanganan Perkara Pidana, Sinar Grafika, Jakarta. 2009, hlm. 16.

${ }^{3}$ Farit Kurniawan, Pertanggung jawaban Pidana orang yang menggadaikan mobil dalam status sewa, UPN, Surabaya, 2011, hlm. 11.

${ }^{4}$ Mahmud Mulyadi, Criminal Policy:Pendekatan Integral Penal Policy dan Non Penal Policy Dalam Penanggulangan Kejahatan Kekerasan, Pustaka Bangsa Press, Jakarta. 2008, hlm. 211.
} 
Incasi Raya Group. Perkebunan tersebut tersebar pada beberapa Kabupaten yang ada di wilayah Sumatera Barat antara lain Kabupaten Pesisir Selatan, Kabupaten Dharmasraya dan Kabupaten Sijunjung. Sepanjang tahun 2018-2020 telah terjadi lebih dari 122 tindak pidana pencurian kelapa sawit pada wilayah perkebunan kelapa sawit milik PT Sumbar Andalas Kencana (SAK) Incasi Raya Group. Angka ini adalah yang dilaporkan pada pihak Kepolisian setempat dan masih banyak lagi kejadian pencurian kelapa sawit yang tidak dilaporkan. Sebagian besar kasus pencurian kelapa sawit diselesaikan dengan berdasarkan Perma Nomor 2 tahun 2012 dan dengan berdasarkan pada prinsip restoratif justice.

Permasalahan yang dibahas adalah Penegakan hukum pada tahap penyidikan terhadap Tindak Pidana Pencurian Kelapa Sawit milik PT. Sumbar Andalas Kencana di Satreskrim Polres Pesisir Selatan.

\section{METODE PENELITIAN}

Spesifikasi penelitian adalah deskriptif analitis, dengan metode pendekatan yuridis normative didukung oleh yuridis empiris. Jenis data yang digunakan adalah data sekunder dan data primer. Data sekunder diperoleh dari studi dokumen, data primer diperoleh dengan cara wawancara. Data yang diperoleh kemudian dianalisa secara kualitatif.

\section{PEMBAHASAN}

A. Penegakan Hukum Pada Tahap Penyidikan Terhadap Tindak Pidana Pencurian Kelapa Sawit Milik PT Sumbar Andalas Kencana di Satreskrim Polres Pesisir Selatan

Berdasarkan wawancara dengan Kapolres Pesisir Selatan bahwa Kepolisian telah melakukan pembinaan berupa penyuluhan hukum dalam satu tahun 2-3 kali guna menanggulangi tindak pidana pencurian kelapa sawit. Selain itu pihak Polres Pesisir Selatan juga melakukan program edukasi kepada masyarakat terutama anak-anak, untuk menanamkan kepada mereka betapa pentingnya keamanan, kenyamanan dan ketentraman dalam kehidupan bermasyarakat.

Berdasarkan wawancara dengan Kapolres Pesisir Selatan penulis dan kuisioner yang penulis lakukan kepada masyarakat dan para pengusaha perkebunan kelapa sawit dapat dilihat bahwa tindakan preventif yang dilakukan oleh Polres Pesisir Selatan tidak berjalan dengan maksiamal karena upaya penyuluhan hukum yang di lakukan banyak tidak di ketahui oleh masyarakat dan para pengusaha perkebunan kelapa sawit, hal ini bisa terjadi karena dua hal, pertama kurang maksimalnya Polres Pesisir Selatan dalam mensosilalisasikan penyuluhan hukum kepada masyarakat dan pengusaha perkebunan, dan kedua, sikap masyarakat yang apatis sehingga tidak ingin tahu dengan apa yang terjadi disekitarnya.

Kemudian pada tindakan represif, diantaranya melakukan penyelidikan Berdasarkan wawancara dengan Kapolres Pesisir Selatan menyatakan bahwa setelah mendapatkan laporan atau aduan akan adannya suatu tindak pidana pencurian kelapa sawit, Kepolisian langsung melakukan penyelidikan dengan melakukan pengamatan, wawancara saksi, pelacakan pelaku dan barang buktinya. Setelah Polres Pesisir Selatan melakukan tahapan tersebut, kemudian barulah kepolisian melakukan gelar perkara apakah suatu peristiwa tersebut merupakah peritiwa pidana atau bukan. 
Setelah melakukan penyelidikan dan telah mendapat titik terang akan tindak pidana tersebut maka selanjutnya pihak kepolisian melanjutkan kasus tersebut ketahap penyidikan. Melakukan Penyidikan Setelah melewati tahapan penyelidikan dan sampailah pada kesimpulan bahwa sebuah peristiwa tersebut adalah peristiwa pidana maka Polres Pesisir Selatan meningkatkan kasus tersebut ketahap Penyidikan. Kemudian Penyidik melakukan pemanggilan terhadap saksi-saksi dan korban untuk di mintai keterangan terkait tindak pidana pencurian kelapa sawit yang terjadi di perkebunan PT Sumbar Andalas Kencana.

Setelah mendapatkan dua alat bukti yang sah penyidik Polres Selatan menjemput tersangka tindak pidana pencurian kelapa sawit di wilayah Polres Pesisir Selatan ketempat tinggalnya dan apabila tersangka berada diluar kota maka pihak Polres Pesisir Selatan akan melakukan kerjasama dengan pihak-pihak terkait.

Penangkapan Dalam kasus pencurian kelapa sawit di Pesisir Selatan telah melakukan penangkapan sebanyak 67 tersangka dari 73 tersangka dalam kurun waktu 2016 s/d 2020. Dari 67 tersangka yang dilakukan penangkapan 14 diantaranya merupakan kasus tertangkap tangan sedang melakukan pencurian kelapa sawit. Dari 67 orang yang dilaaukan penangkapan oleh Polres Pesisir Selatan ini dilakukan berdasarkan pertimbangann bahwa agar tersangka tidak melarikan diri dan tidak berniat untuk menghilangkan alat bukti, guna mempermudah penyidik dalam melakukan penyidikan.

Penahanan Dalam kasus pencurian kelapa sawit diwilayah Polres Pesisir Selatan, kepolisian juga melakukan penahanan terhadap tersangka tindak pidana pencurian kelapa sawit, dari 73 tersangka kasus pencurian kelapa sawit, 67 diantaranya dilakaukan penangkapan dan penahanan, dan 14 diantaranya merupakan pelaku yang tertangkap tangan.

Penyitaan Berdasarkan wawancara dengan Kapolres Pesisir Selatandalam kasus pencurian kelapa sawit di wilayah Polres Pesisir Selatan, selama ini dari 41 jumlah kasus terhitung dari tahun 2016 s/d 2020, dalam melakukan penyidikan kepolisian selalu melakukan penyitaan terutama terhadap alat bukti baik yang ditemukan dilokasi kejadian ataupun alat bukti yang ditemukan jauh dari lokasi kejadian yang merupakan satu kesatuan dari sebuah tindak pidana pencurian kelapa sawit yang terjadi. Adapun bentuk barang yang disita biasanya adalah berupa kendaraan transportasi yang diguanakan oleh pelaku, buah sawit yang tersisa, dan alat-alat yang digunakan untuk mendodos sawit.

Upaya penyelesaian tindak pidana merupakan suatu upaya penyelesaian yang dilakukan oleh penegak hukum terhadap suatu kejahatan atau pelanggaran tindak pidana sesuai dengan apa yang telah diatur dalam peraturan perundang-undangan. Terkait dengan tindak pidana pencurian kelapa sawit tentu suatu upaya yang dilakukan haruslah sesuai dengan ketentuan hukum, menjunjung tinggi nilai keadilan, kemanusiaan dan juga haruslah sesuai dengan peraturan perundang undangan yang berlaku. Selain penyelesaian menggunakan sistem peradilan pidana juga dapat menggunakan sistem perundingan yang upaya penyelesaian diselesaikan oleh pemangku adat atau aparatur nagari dengan mengedepankan proses musyawarah guna tercapainya upaya penyelesaian secara perdamaian. Berdasarkan hasil wawancara dengan penyidik pada Satreskrim Pesisir Selatan, upaya yang dilakukan oleh Polres Pesisir Selatan dalam melakukan upaya penyelesaian terhadap tindak pidana pencurian kelapa sawit di perkebunan PT. Sumbar 
Andalas Kencana menggunakan sistem peradilan adat, yang upaya penyelesaiannya dilimpahkan ke KAN untuk selanjutnya diselesaikan oleh pemangku adat dengan mengedepankan proses musyawarah guna tercapainya upaya penyelesaian secara perdamaian.

Upaya penyelesaian yang dilakukan terhadap pelaku tindak pidana pencurian kelapa sawit tersebut jika baru sekali melakukan tindak pidana pencurian maka terhadap pelaku hanya diberikan pembinaan, wajib lapor, dan pernyataan tidak akan mengulangi lagi tindak pidana pencurian kelapa sawit tersebut. Ketika tindak pidana pencurian itu berulang barulah terhadap pelaku diproses hingga ke tahap pemeriksaan di pengadilan.

Dalam proses penyidikan terhadap tindak pidana pencurian kelapa sawit pihak Polres pesisir Selatan melakukan pemeriksaan terhadap tersangka, dan pemeriksaan terhadap saksi pelapor guna membuat berita acara pemeriksaan. Selain itu pihak Kepolisian Resor Pesisir Selatan juga memanggil keluarga dari tersangka untuk memberikan keterangan mengenai kebenaran status tempat tinggal tersangka. Dalam pelaksanaan penyelesaian tindak pidana pencurian kelapa sawit, terkait tindak pidana pencurian kelapa sawit di perkebunan PT.Sumbar Andalas Kencana yang diselesaikan dengan upaya penyelesaian mediasi dan menggunakan sistem peradilan adat di lingkungan Kabupaten Pesisir Selatan dan mediasi dengan perusahaan sebagai korban. Kepolisian dan desa bekerjasama menyelesaikan menggunakan sistem mediasi dan peradilan adat. Hal ini tidak lain dikarenakan pihak korban terkait dengan tindak pidana pencurian tersebut lebih memilih untuk diselesaikan dengan upaya penyelesaian yang menggunakan sistem mediasi dan peradilan adat.

Polres Pesisir Selatan dalam hal ini pernah menyelesaikan perkara pidana tentang pencurian melalui mediasi. Melalui musyawarah dicarilah kesepakatan antara para pihak untuk mewujudkan keadilan tersebut. Mekanisme mediasi yang dilakukan oleh Polres Pesisir Selatan berdasarkan apa yang telah diatur dalam SEKAP. Setelah dicapai kesepakatan bersama antara pihak yang terlibat penyidik segera menerbitkan surat penghentian penyidikan dengan alasan keadilan restoratif. Tentunya pelaksanaan mediasi pada tindak pidana pencurian kelapa sawit adalah upaya yang dilakukan oleh penyidik dalam mewujudkan peradilan yang sederhana, cepat dan biaya ringan dengan tetap memperhatikan kepasitan, kemanfaatan dan keadilan hukum. Hal tersebut mengingatkan bahwa pada dasarnya berlakunya hukum diharapkan dapat mensejahterahkan kehidupan masyarakat. Pada tindak pidana pencurian tersebut hasil kesepakatan dalam musyawarah bahwa pelaku bersedia dan sanggup untuk mengembalikan kerugian tersebut serta meminta maaf atas perbuatanya terhadap korban.

Penyelesaian tindak pidana pencurian melalui upaya mediasi atau musyawarah yang melibatkan korban, pelaku dan penyidik sebagai mediator sebagai upaya meuwujudkan keadilan restoratif yang dilakukan oleh Polres Pesisir Selatan dengan tujuan pemenuhan keadilan bagi korban dan membebaskan pelaku dari perampasaan kemerdekaan dalam hal ini berdasarkan SEKAP dan peraturan perundang-undangan lainya seperti KUHAP dan Undang-Undang Kepolisian Negara Republik Indonesia. Tidak semua tindak pidana dapat diselesaikan diluar jalur hukum, oleh karena itu SEKAP memberi batasan terkait tindak pidana yang bisa diselesaikan diluar jalur hukum dengan mengedepankan prinsip keadilan restoratif. 


\section{B. Kendala Dalam Penegakan Hukum Pada Tahap Penyidikan Terhadap Tindak Pidana Pencurian Kelapa Sawit Milik PT Sumbar Andalas Kencana di Satreskrim Polres Pesisir Selatan}

Faktor Masyarakat juga menjadi kendala dalam tahap penyidikan. Masyarakat Kabupaten Pesisir Selatan lebih memilih menyelesaikan kasus tersebut dengan adat yang berlaku, meskipun cara-cara seperti itu memang baik adanya tetapi jika dilihat kenyataannya sanksi adat tidak lagi menimbulkan efek jera bagi para pelaku. Masyarakat belum menyadari pentingnya melaporkan /mengadukan kasus pencurian tersebut kepada Polres Pesisir Selatan, dan masih berkembangnya stigma dimasyarakat bawa apabila diselesaikan jalur hukum maka prosedurnya rumit dan bertele-tele.

Kemudian dipengaruhi oleh Faktor Sarana dan Prasarana dan Dana yang terbatas Menurut penjelasan dari penyidik kasus pencurian kelapa sawit di Kabupaten Pesisir Selatan biasanya dilakukan pelaku pada waktu malam hari karena kebun sawit tersebut tidak ada yang mengawasi atau menjaga, sehingga para pelaku lebih bebas melancarkan aksi pencurian kelapa sawit tersebut. Untuk melakukan penangkapan atau pengejaran kepada pelaku pencurian Polres Pesisir Selatan masih mengalami kendala pada mobil operasional karena jarak antara kantor kepolisian dengan kebun sawit yang jauh harus memerlukan mobil operasional/ transportasi yang memadai.

Dalam menghadapi kendala yang dihadapi oleh Polres Pesisir Selatan dalam mengatasi hambatan yang timbul dalam penyidikan terhadap tindak pidana pencurian kelapa sawit, maka Polres Pesisir Selatan melakukan beberapa upaya, diantaranya berupa penambahan personil. Penambahan personil menjadi upaya yang mutlak dilakukan oleh Kepolisian guna menjamin terselenggaranya penyidikan yang baik oleh Polres Pesisir Selatan dalam melaksanakan proses penyidikan tindak pidana pencurian kelapa sawit di wilayah Polres Pesisir Selatan.

Melakukan Kerjasama Dengan Pihak Perusahaan dan Masyarakat Melakukan kerjasama dengan masyarakat dalam hal ini pemuka adat supaya apabila menemukan tersangka pencurian agar melaporkannya ke Polres Pesisir Selatan guna dilakukan penyelidikan sesuai prosedur yang berlaku. Polres Pesisir Selatan juga menganjurkan kepada para pengusaha kelapa sawit yang ada di Kabupaten Polres Pesisir Selatan supaya mendirikan pos-pos pengamanan atau pos satpam disekitar kebun sawit dan juga pemasangan portal-portal penghambat dalam titik-titik tertentu supaya pencurian kelapa sawit di Kabupaten Pesisir Selatan bisa diminimalisir.

Kemudian meminimalisir dana dan mendayagunakan Sarana dan Prasarana yang Ada. Kendala dana menjadi hal yang klasik dalam penegakan hukum yang dialami oleh Polres Pesisir Selatan, maka untuk tetap menjaga citra dan wibawa sebagai garda terdepan dalam penegakan hukum dalam hal ini melakukan penyidikan maka Polres Pesisir Selatan mengupayakan tindakan-tindakan yang efektif dan efisien. Tak terkecuali dalam penyidikan tindak pidana pencurian di wilayah Polres Pesisir Selatan, maka sebelum pencairan dana operasional, maka pengeluaran-pengeluaran akan di cek secara selektif supaya dana yang digunakan memang benar-benar bermanfaat.

Terhadap kurangnya sarana dan prasarana yang mendukung penegakan hukum terhadap penyidikan tindak pidana pencurian kelapa sawit di wilayah Polres Pesisir Selatan, maka Polres Pesisir Selatan mendayagunakan sarana yang tersedia semaksimal 
mungkin. Akan tetapi Polres Pesisir Selatan tetap mengajukan permohonan penambahan satu unit mobil operasional di setiap unit di Polres Pesisir Selatan .

Lebih lanjut beliau mengatakan, jika dalam penyidikan terhadap tindak pidana pencurian kelapa sawit di wilayah Kabupaten Pesisir Selatan terkendala oleh kendaraan, maka Polres Pesisir Selatan menggunakan kendaraan roda dua maupun kendaraan roda empat milik pribadi untuk melakukan tindakan penyidikan. Juga dengan berkerjasama dengan PT. Sumbar Andalas Kencana sehingga dapat menemukan secara cepat apabila terjadi pencurian kelapa sawit di kawasan perkebunan PT Sumbar Andalas Kencana. Hal ini kembali menegaskan keseriusan aparat Polres Pesisir Selatan dalam rangka penyidikan terhadap tindak pidana pencurian kelapa sawit di Kabupaten Pesisir Selatan.

\section{KESIMPULAN}

Penegakan Hukum Yang dilakukan terhadap pelaku tindak pidana pencurian kelapa sawit milik PT. Sumbar Andalas Kencana adalah dengan melalui proses penyidikan dan mediasi penal. Pada awalnya diterapkan mediasi penal dimana pelaku adalah baru sekali melakukan tindak pidana pencurian maka terhadap pelaku hanya diberikan pembinaan, wajib lapor, dan pernyataan tidak akan mengulangi lagi tindak pidana pencurian kelapa sawit tersebut. Ketika tindak pidana pencurian itu berulang barulah terhadap pelaku diproses hingga ke tahap pemeriksaan di pengadilan.

\section{DAFTAR PUSTAKA}

Barda Nawawi Arief, Mediasi Penal: Penyelesaian Perkara di Luar Pengadilan, Pustaka Magister, Semarang, 2008

Khotbul Umam, Penyelesaian Sengketa di Luar Pengadilan, Penerbit Pustaka Yustisia, Yogyakarta, 2010

Leden Marpaung, Proses Penanganan Perkara Pidana, Sinar Grafika, Jakarta. 2009

Farit Kurniawan, Pertanggung jawaban Pidana orang yang menggadaikan mobil dalam status sewa, UPN, Surabaya, 2011

Mahmud Mulyadi, Criminal Policy:Pendekatan Integral Penal Policy dan Non Penal Policy Dalam Penanggulangan Kejahatan Kekerasan, Pustaka Bangsa Press, Jakarta. 2008

Ridwan Hasibuan, Kriminologi Dalam Arti Sempit dan Ilmu-Ilmu Forensik, USU Press, Medan, 1994 